\title{
THE ASSOCIATION STIPETO-CONVOLVULETUM COMPACTI ASS. NOVA IN KOSOVO
}

\author{
Fadil MILLAKU ${ }^{1}$, Elez KRASNIQI ${ }^{1}$ \& Ferat REXHEPI ${ }^{1}$
}

\begin{abstract}
Serpentine vegetation of Kosovo represents a diversity which has not been sufficiently explored, yet. Kosovo's serpentine is spread in different parts of Kosovo at the altitudes of 400-2100 m. Large complexes with serpentine are found in the north of Kosovo, but the southern part of Kosovo is also rich in serpentine rocks and in endemic species.

Using the principles and methods of the Zürich-Montpellier School we have explored the serpentine flora and vegetation of Gurana, an area in the south-east of Kosovo near the border with the Republic of Macedonia. This area has not been sufficiently researched because of the militarized border areas. During the research of these fields, we found species that were not present on the other serpentines of Kosovo.

The species Convolvulus compactus Boiss. (syn. Convolvulus cochlearis) and Stipa mayeri dominate this terrain and create stands that we have classified as the association Stipeto-Convolvuletum compacti ass. nova. This association was researched during 2007-2010. Based on the results obtained and comparing them with the results of other authors, we have arrived at the conclusion that we are dealing with a new association which we called Stipeto-Convolvuletum compacti ass. nova.
\end{abstract}

Key words: Vegetation of Kosova, Gurana, Serpentine terrains.

\section{Izvleček}

Vegetacija Kosova na serpentinitu je posebnost, ki do sedaj še ni bila zadovoljivo raziskana. Serpentinit je na Kosovu razširjen na različnih območjih na nadmorskih višini od 400 do 2100 metrov. Večje površine najdemo na severu Kosova, vendar je tudi južni del bogat s serpentinitom in endemičnimi vrstami.

$\mathrm{Z}$ züriško-montpelliersko metodo smo preučili floro in vegetacijo na serpentinitu pri vasi Gurana v jugovzhodnem delu Kosova ob meji z Republiko Makedonijo. To območje do sedaj ni bilo dobro raziskano zaradi vojaške navzočnosti na obmejnem območju. Na tem delu smo našli vrste, ki jih ne najdemo na drugih območjih s serpentinitom na Kosovu.

Vrsti Convolvulus compactus Boiss. (sin. Convolvulus cochlearis) in Stipa mayeri prevladujeta na teh območjih in gradita sestoje, ki smo jih uvrstili v asociacijo Stipeto-Convolvuletum compacti ass. nova. Raziskovali smo v letih od 2007 do 2010. Na podlagi dobljenih rezultatov in s primerjavo z drugimi avtorji smo prišli do zaključka, da lahko te sestoje uvrstimo v novo asociacijo, ki smo jo poimenovali Stipeto-Convolvuletum compacti ass. nova. Ključne besede: vegetacija Kosova, Gurana, območja serpentinita.

\section{INTRODUCTION}

Serpentine is a rare bedrock on the surface of the earth (Kruckeberg 1985). In Kosovo territory there have been found serpentine rocks which are very rich, from the aspect of flora and vegetation (Rexhepi 1985, Krasniqi \& Millaku 2007).
The serpentine rocks in the Gurana area belong to the Jurassic age. These serpentines are poor in biogenic elements necessary for plant life; nevertheless, about 98 species are present in these terrains. Analyses made by Pavičević et al. (1974) have proved that the chemical composition of Gurana serpentines is very similar to other ser-

\footnotetext{
${ }^{1}$ UP (University of Prishtina), The Faculty of Mathematics and Natural Sciences; Nëna Terezë str. n.n. 10000, Prishtinë, Kosovë, fadilmillaku@hotmail.com, elez_krasniqi@yahoo.com, feratrexhepi@yahoo.com
} 
pentines in the Balkans. In the Gurana area, about $70 \%$ of the serpentines present contain less than $3 \% \mathrm{CaO}$, where typical serpentine species dominate, and serpentines with $\mathrm{CaO}$ content exceeding $30 \%$, where typical serpentine species are dominant, but also some species characteristic of carbonate rocks are present.
Flora and vegetation in serpentine terrains in Kosovo have been investigated by many researchers, such as: Blečić et al. (1969), Blečić \& Krasniqi (1971), Krasniqi (1972, 1987), Hundozi (1987), Rexhepi (1978, 1979, 1982, 1997, 2000), Rexhepi \& Millaku (1996), Krasniqi (2003, 2006), Krasniqi \& Millaku (2004) and Millaku et al. (2007).

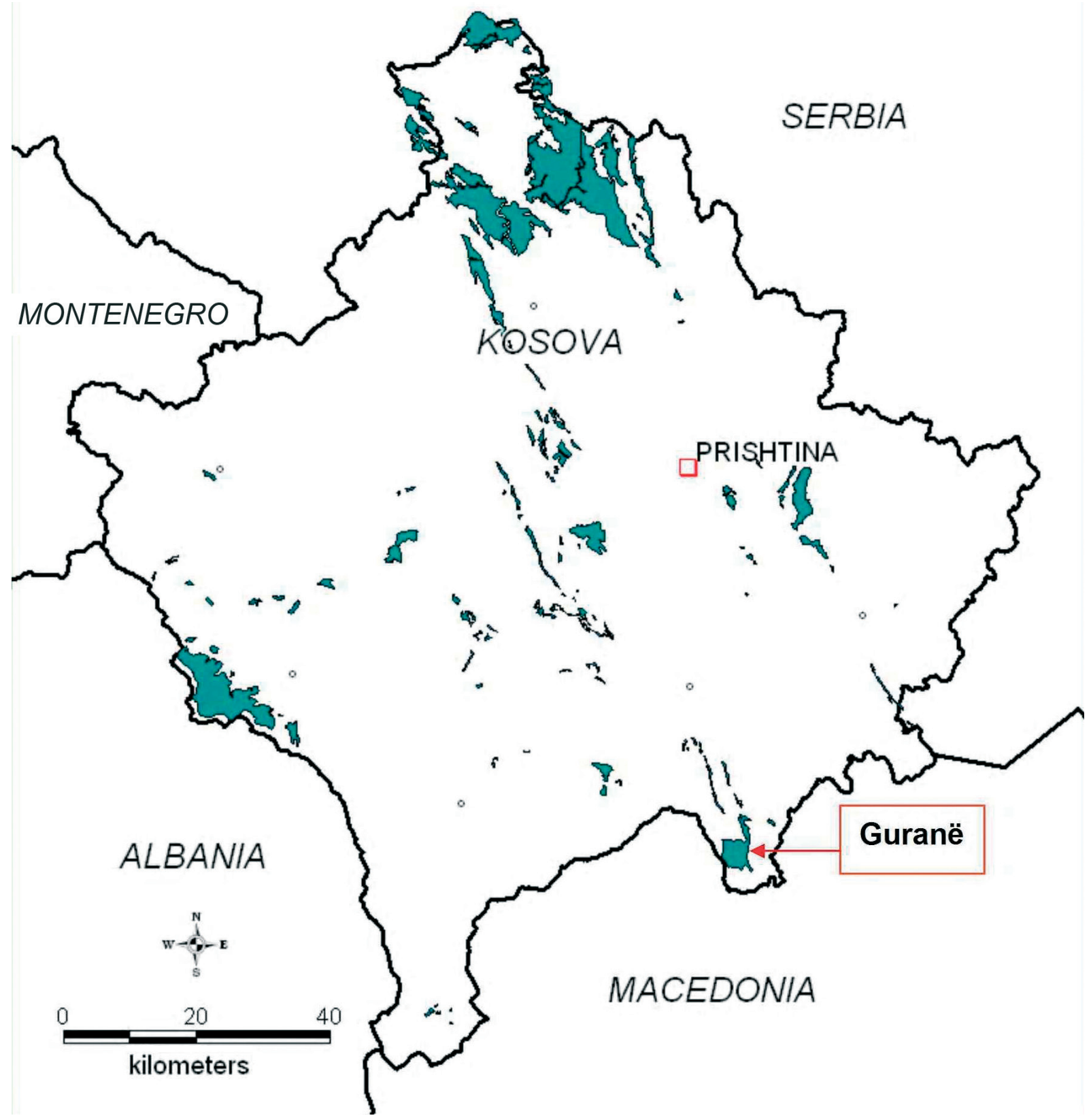

Figure 1: Map of the serpentine massifs spread on Kosovo (Ibër river valley (North Kosovo, near Mitrovica), Drini i Bardhë valley (Gubavc, near Peja), Brezovica massive, Kozniku massive and Guranë (on the foot of the Luboteni Mountain).

Slika 1: Zemljevid območij serpentinita na Kosovu (dolina reke Ibër (severni del Kosova, v bližini Mitrovice), dolina Drini i Bardhë (Gubavc, pri Peći), masivi Brezovica, Kozniku in Guranë (na vznožju gore Luboteni). 


\section{MATERIALS AND METHODS}

\subsection{Description OF THE RESEARGHED AREA}

The research area spreads on the eastside of the Luboten mountain, near the village of Gurana and near the area bordering Macedonia. In general, typical serpentine flora and vegetation is dominant, while around this area there are oak forests in which Quercus pubescens prevails. Sites of the association Stipeto-Convolvuletum compacti ass. nova in Gurana are serpentine pastures located at an altitude of 550-800 $\mathrm{m}$ above sea level (Figure 1). The land is degraded. Considering its chemical-physical features, serpentines in Gurana area are unfavourable biotopes for plant growth and development. The serpentine rocks in this area are easily crumbled, thus creating a dry rocky land. The soil color is black, therefore the soil can warm up quickly and plants are exposed to high temperatures during summertime and to high temperature amplitudes throughout all seasons. The serpentines are poor in some important bio-elements such as Ca, K, P, whilst on the other hand they contain some poisonous elements for the plants such as: Ni, Cr, Co etc. The serpentines contain a high content of magnesium $(\mathrm{Mg})$, which is poisonous for many plant species when in high concentration (Rexhepi 1979, 1990). The climate is characterized by Sub-Mediterranean conditions which enter through the Lepenci river valley. During the summer the temperatures are high and rainfalls are rare. It is the area with less recorded rains in the Republic of Kosovo (under $500 \mathrm{~mm}$ per year) (Tahirsylaj \& Asllani 2009).

The association is located next to the village Gurana (Hani i Elezit), where the pasture is well developed. Therefore the stands are rather degraded and species poor.

\subsection{Methods}

Phytocenological relevés in Gurana serpentines were made during 2007 and 2010. The phytocoenological research studies are made using the principles and methods of the Zürich-Montpellier School (Braun-Blanquet 1964).

Major activities in the field were identification and determination of homogeneous plots. This was achieved on the basis of field analyses, and floristic composition of each relevé on a singular site, together with other additional data, such as number of relevé, altitude, exposition of terrain, slope, geological composition and the size of each relevé $\left(\mathrm{m}^{2}\right)$. Species characteristic of higher syntaxa were assigned according to Rexhepi (1978, 1982), Mucina et al. (1993), Čarni et al. (2000) and Buzo (2005). The floristic composition of communities is presented as per the principles for characteristic species. The arrangement of all species into syntaxonomic categories is presented according to the degree of presence - constancy, beginning from grade $\mathrm{V}$ to I in phytocoenological table (Table 1).

Species were determined using the required literature such as: Tutin et al. (1964-1980), Jordanov (1963-1982), Josifović (1970-1977), Dakov (1984), Paparisto et al. (1988, 1992), Qosja et al. (1992), Polunin (1997), Vangjeli et al. (2000) and Matevski (2010).

New syntaxa were described according to rules of the International Code of Phytosociological Nomenclature (Weber et al. 2000).

\section{RESULTS}

\subsection{FloRistiC GOMPOSITION OF COMMUNITY}

The floristic composition of the community is presented in the phytocoenological table (Table 1), which contains 10 relevés. In the table, there are 98 species present. Characteristic species of the association are Convolvulus compactus, Stipa mayeri, Achillea coarctata, and Agropyron cristatum.

\section{Convolvulus compactus Boiss. (Figure 2)}

Syn: C. boessieri Steudel subsp. compactus (Boiss.) Stace in Bot. J. Linn. Soc. 64: 58 (1971); C. boissieri subsp. parnassicus (Boiss \& Orph.) Kuzm. In Jordanov, Fl. Nar. Rep. Bulg., 8: 451 (1982), (Matevski 2010); C. cochlearis Gris. Spic. Flora SR Srbije 10: 164 (1986).

Dwarf, cushion-like, densely oppressed-pubescent perennial up to $10 \mathrm{~cm}$; stems much-branched, woody. Leaves $4-10 \mathrm{~mm}$ long, 4-7 mm broadly linear to obovate. The plant is entirely covered with silver-silk hair and respectively colored. Peduncles are very short, terminal and axillary, 1-flowered. Corolla 20-22 mm, white to purple. Distributed in the Asiatic part of Turkey and the Balkan peninsula: Bulgaria, Albania, Macedonia and Kosovo (only in Guranë). In Macedonia 


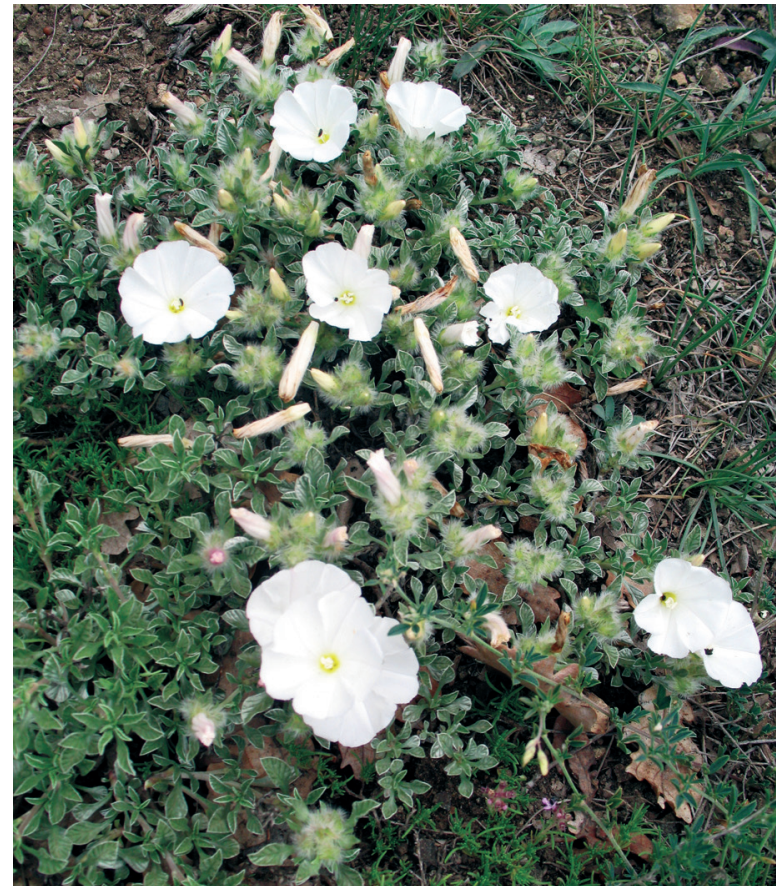

Figure 2: Convolvulus compactus, the characteristic species of the association Stipeto-Convolvuletum compacti (Photo: F. Millaku, Guranë, 2009).

Slika 2: Convolvulus compactus, značilna vrsta asociacije Stipeto-Convolvuletum compacti (Foto: F. Millaku, Guranë, 2009).

(Matevski 2010) and Kosovo (Rexhepi 2000) it is distributed only on the serpentines and is the main component of the phytocoenose.

\section{Stipa mayeri Martinovsky (Figure 3)}

It is a perennial herbaceous plant, with the stem up to $50 \mathrm{~cm}$ length. It is an endemic species of Kosovo. It was discovered by the Czech botanist Jan Otokar Martinovsky in 1971 (Rexhepi 2000), from the herbarium material collected previously on serpentine territory of Kosovo by the Slovenian botanist E. Mayer, by whom it was named. In Kosovo it is spread in Mirushë, Koznik and Gurana. It is characteristic species of the association.

The association Stipeto-Convolvuletum compacti ass. nova is well differentiated in its floristic structure. The characteristic species of the association and some serpentinophyte species are usually present in this association. There exist differences in the aspect of flora and vegetation of Gurana, where the association Stipeto-Convolvuletum compacti is located, and other serpentines. This is a consequence of the climate conditions,

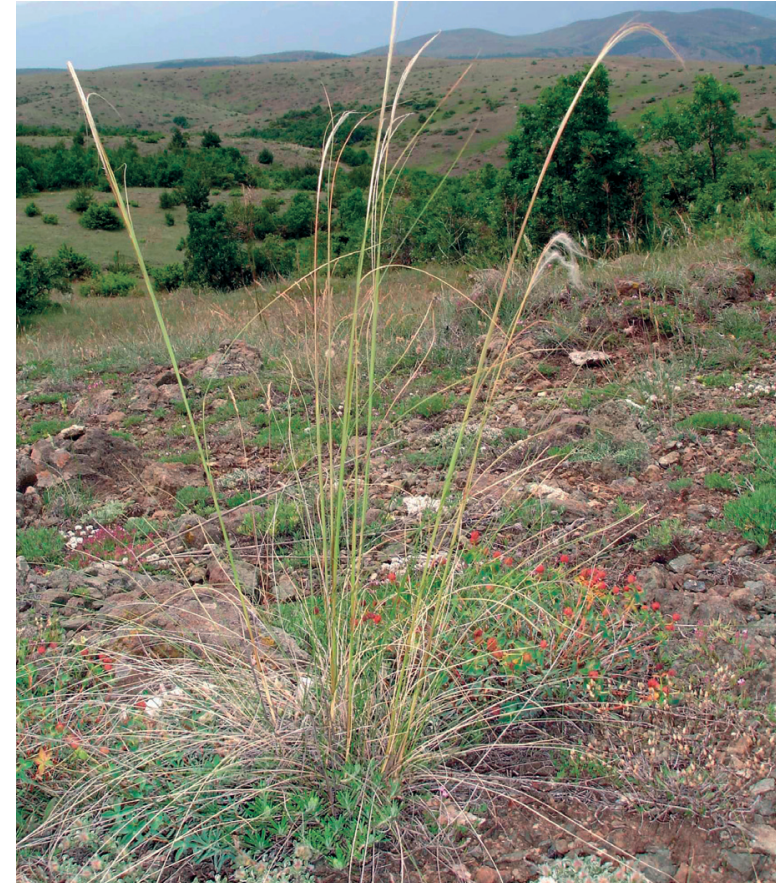

Figure 3: Stipa mayeri, the characteristic species of the association Stipeto-Convolvuletum compacti and endemic species of Kosovo (Photo: E. Krasniqi, Guranë, 2009).

Slika 3: Stipa mayeri, značilna vrsta asociacije Stipeto-Convolvuletum compacti in endemična vrsta Kosova. (Foto: E. Krasniqi, Guranë, 2009).

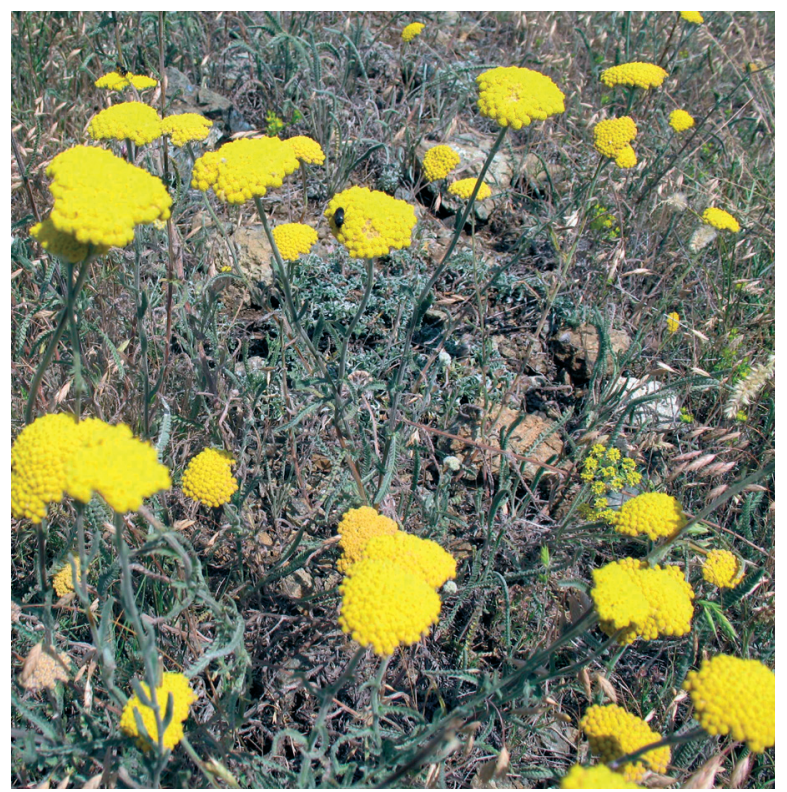

Figure 4: Achillea coarctata, the characteristic species of the association Stipeto-Convolvuletum compacti (Photo: E. Krasniqi, Guranë, 2008).

Slika 4: Achillea coarctata, značilna vrsta asociacije StipetoConvolvuletum compacti. Foto: E. Krasniqi, Guranë, 2008. 


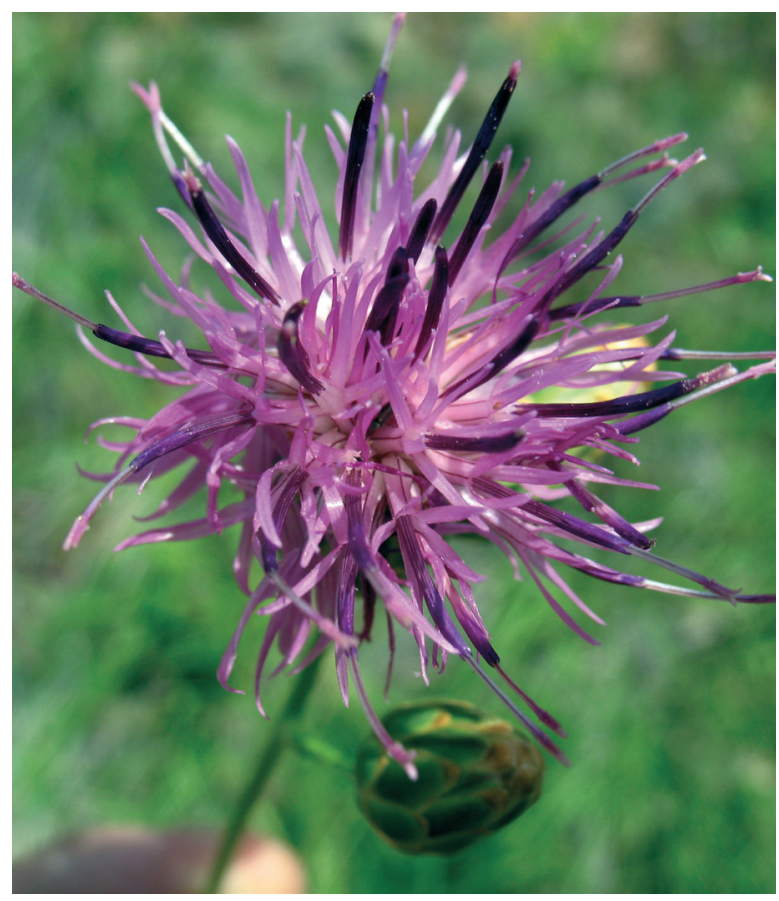

Figure 5: Centaurea kosanini, Balkan endemic species present only on the serpentines (Photo: F. Rexhepi Guranë 2009).

Slika 5: Centaurea kosanini, endemit Balkana, ki ga najdemo le na serpentinitu. (Foto: F. Rexhepi, Guranë, 2009).

geographic position and floristic structure. Thus, endemic species: Genista hassertiana, Aster albanicus, Forsythia europaea, Tulipa scardica, Aristolochia merxmuelleri, Halacsya sendtneri, Linum elegans, Saponaria intermedia, Veronica andrazovszkyi, that belong to the associations: Polygalo-Genistetum hasertianae, Potentillo-Fumanetum bonapartei, Astero-funipertum oxycedri, Sedo-Bornmullerietum dieckii are not present in the association StipetoConvolvuletum compacti; whereas species Convolvulus compactus, Achillea coarctata, Iris pallida and Colchicum hungaricum, which are present in this association, are absent in the associations mentioned above. The association Stipeto-Convolvuletum compacti ass. nova belongs to the alliance Centaureo-Bromion fibrosi Bleč. et al. 1969, order Halacsyetalia sendtneri Rt. 1970 and in the class Festuco-Brometea Br. Bl. et R. Tx. 1943.

\subsection{Community Description}

The association Stipeto-Convolvuletum compacti ass. nova (Figure 6) is spread in Gurana area, in the serpentine rocks, in the black soil crumbled up easily, thus creating a dry rocky land. The altitude of these terrains varies between 550-800 m. There are mostly South, West, South-East, SouthWest and East expositions, while the terrain inclination is $10-35$ degrees. The soil is relatively degraded - typical rendzina on serpentine. The community is being developed in the form of open type because of the terrain configuration. In these terrains degradation of soils and vegetation is evident. The characteristic species of the association are: Convolvulus compactus, Stipa mayeri, Achillea coarctata and Agropyron cristatum.

The association Stipeto-Convolvuletum compacti Millaku et al. ass. nova belongs to the alliance Centaureo-Bromion fibrosi Bleč. et al. 1969, which is represented with a considerable number of species with constancy V and IV such as: Thymus lykae, Alyssum markgrafii, Euphorbia glabriflora, Bromus fibrosus [B. erectus subsp. fibrosus], Galium lucidum [G. gerardi] (Rexhepi 1978, 1982, 1994, 2007; Krasniqi \& Millaku 2007). Also the order Halacsyetalia sendtneri Rt. 1970 (Rexhepi 1982, 2007; Krasniqi \& Millaku 2007) is represented with an appreciable number of species with higher constancy, such as: Astragalus onobry-

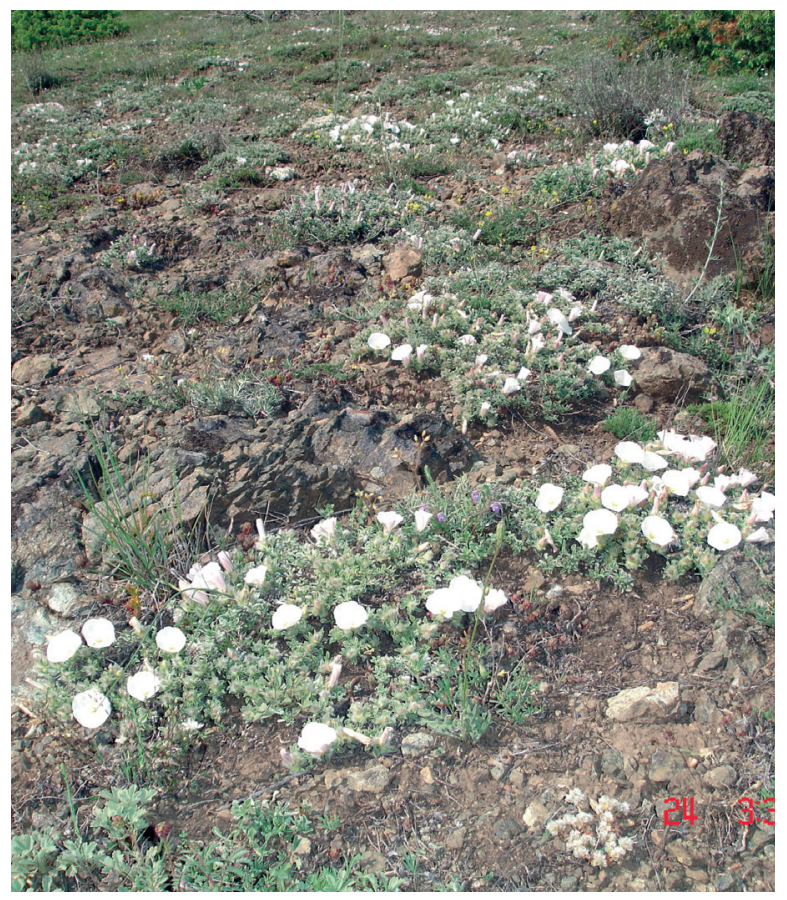

Figure 6: Characteristic appearance of the association Stipeto-Convolvuletum compacti in Gurana serpentines (Photo: F. Millaku 2010).

Slika 6: Značilni videz sestojev asociacije Stipeto-Convolvuletum compacti na serpentinitu na območju Gurana. (Foto: F. Millaku, 2010). 
chis, var. multijugus, Plantago holosteum, Potentilla tommassiniana, Potentilla astracanica, Goniolimon collinum and Linum tauricum.

The class Festuco-Brometea Br.-Bl. et R. Tx. 1943 (Rexhepi 1978, 1994, 2007, Krasniqi. \& Millaku 2007), is represented with 48 species, of which 8 have the constancy V and IV, 20 species have the constancy III, whereas 16 species have the constancy II (Table 1).

The ecological characteristics of the association Stipeto-Convolvuletum compacti ass. nova were obtained on the basis of life forms analysis (Figure 7). The biological spectrum shows the following relationship given in percentage: $\mathrm{H}$ (71\%),

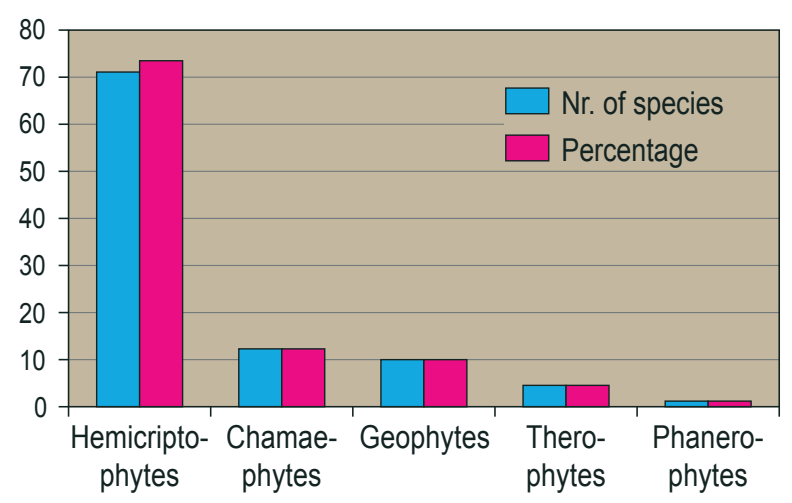

Figure 7: The biological spectrum of association Stipeto-Convolvuletum compacti.

Slika 7: Biološki spekter asociacije Stipeto-Convolvuletum compacti.

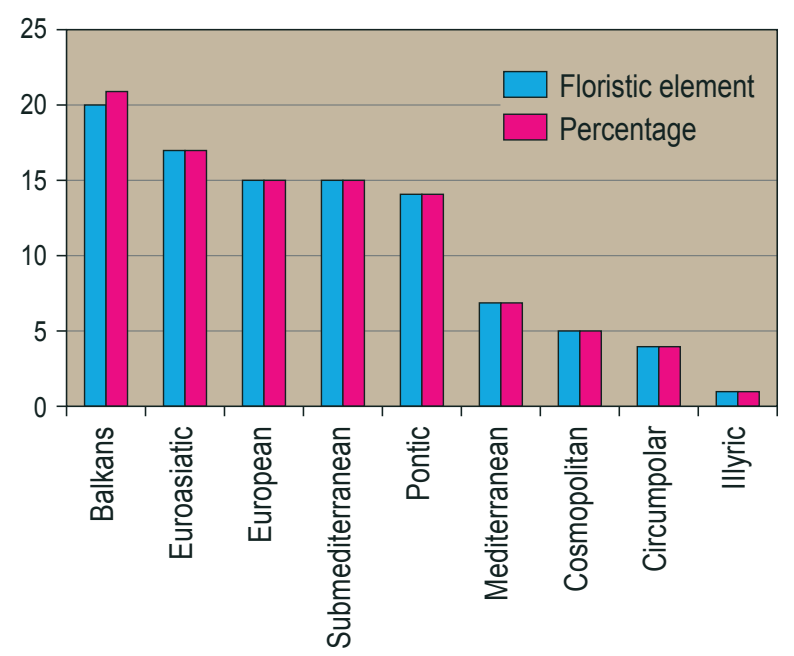

Figure 8: The areal spectrum of the association Stipeto-Convolvuletum compacti.

Slika 8: Spekter flornih elementov asociacije Stipeto-Convolvuletum compacti.
$\mathrm{CH}(12 \%), \mathrm{G}(10 \%) \mathrm{T}(4 \%)$ and P only $1 \%$. Judging by the biological spectrum, we may conclude that in this case we are dealing with a hemicryptophytic community.

The geographical position of this community can be illustrated through the spectrum of species distribution (Figure 8). The distribution of floristic elements of the community is: Balkans (21\%), European (15\%), Euroasiatic (17\%), SubMediterranean (15\%), Pontic (14\%), Mediterranean (7\%), Cosmopolitan (5\%), Circumpolar (4\%) and Illyric (1\%), The southern thermophilous elements (Balkans, Mediterranean and SubMediterranean) indicate the xerothermophilous character of the community. This community has no relevant economic importance, but it is important as a natural safeguard from erosion of the soil.

\subsection{SyntAXonOMiGAL SGHEME}

Festuco-Brometea Br.-Bl. et R. Tx. 1943

Halascyetalia sendtneri Rt. 1970

Centaureo-Bromion fibrosi Blečić et al. 1969 Stipeto-Convolvuletum compacti ass. nova hoc loco

\section{Nomenclatural remark}

Holotypus: Table 1/3 - holotypus hoc loco

Ecological circumstances: Convolvolus compactus dominated grasslands on serpentine bedrock.

\section{CONCLUSIONS}

Phytocenological research conducted in serpentine terrains on Gurana resulted in the establishment of a new association of serpentine pastures named Stipeto-Convolvuletum compacti as. nova. Its characteristic species include Convolvulus compactus, Stipa mayeri, Achillea coarctata and Agropyron cristatum and some endemic and serpentinophyte species such as: Colchicum hungaricum, Iris pallida, Alyssum markgrafii and Bromus fibrosus with high constancy.

The Species Convolvulus compactus in Kosovo is spread only in the Gurana area on this association.

Stipeto-Convolvuletum compacti is mostly similar with the association Hyperico-Euphorbietum glabriflorae Rexhepi 1978, but in the ass. Hyperico-Euphorbietum glabriflorae the following species 
are absent: Convolvulus compactus, Stipa mayeri, Achillea coarctata, Thymus lykae, Centaurea kosaninii, Scabiosa fumaroides, Polygala doerfleri, Sedum serpentinii, Iris pallida, Goniolimon collinum, Linum tauricum, Silene paradoxa, Colchicum hungaricum, Teucrium polium and Centaurea napulifera.

Association Stipeto-Convolvuletum compacti is different from the ass. Potentillo-Fumanetum bonapartei Rexhepi 1979, because in the association Potentillo-Fumanetum bonapartei, the following species are absent: Convolvulus compactus, Achillea coarctata, Thymus lykae, Poa badensis, Centaurea kosaninii, Scabiosa fumaroides, Polygala doerflerii, Iris pallida, Colchicum hungaricum, Teucrium polium and Centaurea napulifera.

Association Stipeto-Convolvuletum compacti have the largest differences in the floristic aspect compared with associations: Cynancho-Saponarietum intermediate Blečić et al 1969, Onosmo-Scabiosetum fumaroides Rexhepi 1978, Sedo-Bornmueleretum dieckii Blečić et al. 1969 and Polygalo-Genistetum hassertianae Blečić et al. 1969.

\section{APPENDIX}

Species in only one relevé:

Allium flavum 2: +, Centaurium erythraea 2: +.1, Chamaespartium saggitale $3:+.2$, Clinopodium vulgare 2: +, Conyza canadensis 6: +, Crocus chrysanthus 9: 1.1, Fraxinus ornus 2:+, Helianthemum nummularium 4: +.2 , Muscari racemosum 10: +, Potentilla detommasii 2: +.1, Quercus pubescens 3: +, Scilla autumnalis 10: +.2 , Scilla bifolia $9:+$. Tulipa sylvestris 9: +.

\section{AKNOWLEDGEMENTS}

We would like to thank Andraz Čarni for literature and professional collaboration. We would like to thank the reviewers for their contribution and comments on our paper.

\section{REFERENCES}

Blečić, V., Tatić, B. \& Krasniqi, F. 1969: Tri endemične zajednice na serpentinskoj podlozi Srbije. Acta Botanica Croatica 28: 43-47.

Blečić, V. \& Krasniqi, F. 1971: Zajednica endemičnog šibljaka forzicije i krtušca (PolygaloForsythietum europaeae) u jugozapadnoj Srbiji.
Glas. Repub. Zav. Zaš. Prir. Muz. Titograd, 4: 35-40.

Braun Blanquet, J. 1964: Pflanzensoziologie. Grundzüge der Vegetationskunde. 3. Aufl. Springer Verlag, Wien, 865 pp.

Buzo, K. 2005: Gjeobotanika. SHBLU, Tiranë, 292 pp.

Čarni, A., Konstandinovski, M. \& Matevski V. 2000: "Saum" (fringe) vegetation (Trifolio-Geranietea) in the Republic of Macedonia, Acta Botanica Croatica 59(1): 279-329.

Dakov, M. (ed.). 1984: Červena kniga na NR Bulgaria, Tom 1 Rastenia, Sofia, 298 pp.

Hundozi, B. 1987: Salvio-Scorzoneretum villosae. Buletini i punimeve shkencore, FSHMN, 10: 132-138.

Jordanov, D. (ed.), 1963-1982: Flora na NR Bulgaria I-VIII. BAN. Institut po botaniku $\mathrm{s}$ botanička gradina (glavni redaktor Daki Jordanov), Sofia.

Josifović, M. (ed.) 1970-1977: Flora S. R. Srbije I-IX, SANU, Beograd.

Krasniqi, F. 1987: Endemics in flora of Kosova and the problem of their protection. ANU BiH. Posebna izdanja, Odjeljenje Prirodnih i Matematičnih Nauka, Sarajevo, 14: 119-124.

Krasniqi, E. 2003: Flora vaskulare e Rajonit të Mirushës, Punim i magjistraturës, UP, FSHMN, Prishtinë, 219 pp.

Krasniqi, E. 2006: Flora dhe vegjetacioni i Malit Drenicë, Disertacion i doktoratës, UP, FSHMN, Prishtinë, $240 \mathrm{pp}$.

Krasniqi, E. \& Millaku, F. 2004: Aster albanicus Deg., përhapja në Shqipëri e Kosovë, vitaliteti ekologjik dhe vendndodhje të reja në territorin e Kosovës, Studime Biologjike 9: 120-125.

Krasniqi, F. 1972: Šumska vegetacija brdskog regiona Kosova. Zajednica Naučnih Ustanova Kosova, Studije, Knjiga 27, Priština, 133 pp.

Krasniqi, E. \& Millaku, F. 2007: The association Hyperico-Euphorbietum glabriflorae Rexhepi 1978 in the serpentine terrains of Drenica Mountain. Hacquetia 6 (2): 183-193.

Kruckeberg, A. 1985: California serpentines: Flora, vegetation, geology, soil and management problems. University of California Press, 180 pp.

Matevski, V. 2010: Flora na Republika Makedonija, Makedonska Akademija na Naukite i Umetnostite, Tom. II, Sv. 1, Skopje, 69 pp.

Micevski, K. 1970: Astragalo-Potentilletalia, nov vegetaciski red na brdskite pasišta vo Macedonija. Makedonska Akad. na Naukite i Umetnostite 2 (2): 15-23. 
Micevski, K. 1985-2005: The Flora of SR Macedonia 1-6. Makedonska Akademija na Naukite i Umetnostite. Skopje.

Millaku, F., Heiselmayer, P., Rexhepi, F., Krasniqi, E., Eichberger, C \& Hazir, A. 2007: Endemic, stenoendemic and relict plants in serpentines of Kosova. Sauteria 16: 149-162.

Mucina, L., Grabherr, G. \& Ellmauer Th. 1993: Die Pflanzengesellschaften Österreichs, Teil I. Antropogene Vegetation (Festuco-Brometea), Gustav Fischer, Stuttgart, 578 pp.

Paparisto, K. \& al. 1988: Flora e Shqipërisë 1, (Akademia e Shkencave të RPSSH, Qendra e Kërkimeve Biologjike), Tiranë, 460 pp.

Paparisto, K. \& al. 1992: Flora e Shqipërisë 2 (Akademia e Shkencave të RSH, Qendra e Kërkimeve Biologjike), Tiranë, 446 pp.

Pavičević, N., Grujić, U., Milošević, Lj., Katalina, P. \& Vasić, G. 1974: Pedološka karta SAP Kosova razmere $1: 50.000$ ), Beograd.

Polunin, O. 1997: Flowers of Greece and the Balkans (a field guide), Oxford Universsity Press, Oxford, New York, Tokyo, 592 pp.

Qosja, Xh. \& al. 1992: Flora e Shqipërisë 3 (Akademia e Shkencave të RSH, Qendra e Kërkimeve Biologjike), Tiranë, 331 pp.

Rexhepi, F. 1978: Zeljaste zajednice brdskog regiona Kosova. Doktorska disertacija, Novi Sad, 113-121.

Rexhepi, F. 1979: Kontribut për njohjen e florës së serpentines në Kosovë. Bioteknika 1-2: $53-70$.
Rexhepi, F. 1982: Vegjetacioni i Kosovës dikur dhe sot. Përparimi 2: 229-259.

Rexhepi, F. 1982: Vegjetacioni i Kosovës dikur dhe sot, Përparimi 3: 383-422.

Rexhepi, F. 1985: Mbrojtja e florës dhe Vegjetacionit në serpentinet e Kosovës. Natyra e Kosovës 5: 61-72.

Rexhepi, F. \& Millaku, F. 1996: Gjinia Potentilla L. në Ballkan. Buletini i FSHMN-së 11: 161-168.

Rexhepi, F. 1997: Mediterranean, Submediterranean and Illyric floristic elements in the Kosovo's flora (Yugoslavia). Bocconea 5 (2): 451-456.

Rexhepi, F. 2000: Bimët endemike të Kosovës, UP, Prishtinë, $150 \mathrm{pp}$.

Rexhepi, F. 2007: The vegetation of Kosova (1), Mapgraphition and phythocenological investigation (Complementary edition in English). UP, FNS, Prishtinë, 137 pp.

Sarić, M., (ed.) 1986: Flora S. R. Srbije X, SANU, Beograd, 164 pp.

Tahirsylaj, S. \& Asllani, A. 2009: Bioklima dhe vlerësimet bioklimatike në Republikën e Kosovës. Iliria 5: 185-298.

Tutin, T. G. et al. 1964-1980: Flora Europaea 1-5, Cambridge, At the University Press.

Vangjeli, J. \& al. 2000: Flora e Shqipërisë 4 (Akademia e Shkencave të RSH, Instituti i Kërkimeve Biologjike), Tiranë, 502 pp.

Weber, H. E. Moravec, J. Theurillat, J.P. \& al. 2000: International Code of Phytosociological Nomenclature. $3^{\text {rd }}$ edition. Journal of Vegetation Science 11: 739-763. 
Table 1: Association Stipeto-Convolvuletum compacti ass. nova.

Tabela 1: Asociacija Stipeto-Convolvuletum compacti ass. nova.

\begin{tabular}{|c|c|c|c|c|c|c|c|c|c|c|c|c|c|}
\hline & Nr. of relevé & 1 & 2 & 3 & 4 & 5 & 6 & 7 & 8 & 9 & 10 & \multirow{7}{*}{ 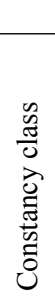 } & \multirow{7}{*}{ 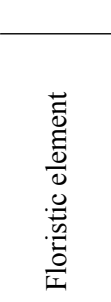 } \\
\hline & Locality & \multicolumn{10}{|c|}{ Guranë } & & \\
\hline & Altitude (m) & 700 & 668 & 700 & 735 & 665 & 681 & 672 & 650 & 650 & 680 & & \\
\hline & Exposition & $\mathrm{W}$ & W & SW & SW & $\mathrm{S}$ & $\mathrm{S}$ & SE & $\mathrm{E}$ & $\mathrm{W}$ & S & & \\
\hline & Slope & 20 & 30 & 20 & 30 & 35 & 30 & 30 & 25 & 15 & 10 & & \\
\hline \multirow{3}{*}{$\begin{array}{l}\text { Life } \\
\text { form }\end{array}$} & Geological substratum & \multicolumn{10}{|c|}{ Serpentine } & & \\
\hline & Size of relevé $\left(\mathrm{m}^{2}\right)$ & 25 & 25 & 25 & 25 & 25 & 25 & 25 & 25 & 25 & 25 & & \\
\hline & \multicolumn{13}{|c|}{ Character species of association Stipeto - Convolvuletum compacti } \\
\hline $\mathrm{CH}$ & Convolvulus compactus & 3.4 & 4.4 & 3.4 & 4.4 & 4.5 & 4.5 & 4.5 & 5.5 & 3.3 & 2.3 & V & Balk. \\
\hline $\mathrm{H}$ & Stipa mayeri & 3.3 & 2.2 & 1.2 & 2.2 & 2.2 & 2.3 & 1.2 & + & + & + & $\mathrm{V}$ & Balk. \\
\hline $\mathrm{H}$ & Achillea coarctata & 2.2 & 1.2 & +.2 & + & 1.1 & + & 1.1 & 1.1 & 1.1 & + & $\mathrm{V}$ & Pont. \\
\hline $\mathrm{H}$ & Agropyron cristatum & 1.2 & 1.2 & 1.2 & . & 1.2 & 1.1 & 1.2 & 1.1 & 1.1 & + & V & Eur. \\
\hline \multicolumn{14}{|c|}{ Character species of alliance Centaureo - Bromion fibrosi Bleč. et al. 1969} \\
\hline $\mathrm{CH}$ & Thymus lykae & 3.4 & 1.2 & 1.2 & 2.2 & 2.3 & 2.3 & 2.3 & 1.2 & . & + & $\mathrm{V}$ & Balk. \\
\hline $\mathrm{CH}$ & Alyssum markgrafii & 1.2 & 1.2 & 2.2 & 2.2 & 1.2 & 1.2 & 1.1 & + & . & 1.1 & $\mathrm{~V}$ & Balk. \\
\hline $\mathrm{CH}$ & Euphorbia glabriflora & 1.2 & 1.2 & . & 1.2 & 1.2 & 1.1 & 1.2 & 1.1 & + & + & V & Balk. \\
\hline $\mathrm{H}$ & Bromus fibrosus $[$ B. erectus subsp. fibrosus] & 1.2 & 1.1 & 1.1 & . & 1.1 & 1.2 & . & . & 1.1 & + & IV & Eur. \\
\hline $\mathrm{H}$ & Galium lucidum $[$ G. gerardi $]$ & . & +.2 & + & + & . & . & 1.2 & 1.1 & . & + & IV & Submed. \\
\hline $\mathrm{H}$ & Scorsonera austriaca & 1.1 & 1.1 & +.2 & . & . & . & . & . & 1.1 & 1.1 & III & Pont. \\
\hline $\mathrm{CH}$ & Fumana bonapartei & +.2 & +.2 & +.2 & . & . & . & . & . & + & + & III & Balk. \\
\hline $\mathrm{H}$ & Centaurea kosaninii & +.2 & . & . & +.2 & + & 1.1 & . & . & . & . & III & Balk. \\
\hline $\mathrm{H}$ & Poa badensis & . & . & +.2 & +.2 & . & . & . & . & + & + & III & Eur. \\
\hline $\mathrm{H}$ & Scabiosa fumaroides & . & +.2 & +.2 & . & + & + & . & . & + & . & III & Balk. \\
\hline $\mathrm{H}$ & Hypericum barbatum & . & + & + & + & . & . & . & . & 1.1 & + & III & Balk. \\
\hline $\mathrm{H}$ & Polygala doerflerii & . & . & . & . & + & . & + & + & . & . & II & Balk. \\
\hline $\mathrm{H}$ & Potentilla australis & . & . & . & + & . & . & . & . & + & + & II & IIlyric \\
\hline $\mathrm{H}$ & Sedum serpentini & . & . & . & . & + & + & . & + & . & . & II & Balk. \\
\hline G & Iris pallida & . & . & . & . & . & . & . & . & 1.2 & 1.1 & I & Balk. \\
\hline \multicolumn{14}{|c|}{ Character species of order Halacsyetalia sendtneri Rt. 1970} \\
\hline \multirow[t]{2}{*}{$\mathrm{H}$} & Astragalus onobrychis & & & & & & & & & & & & \\
\hline & var. multijugus & 1.3 & 1.2 & +.2 & +.2 & 1.2 & 2.2 & . & . & 1.2 & + & $\mathrm{V}$ & Pont. \\
\hline $\mathrm{H}$ & Plantago holosteum & 1.2 & . & + & . & 2.2 & 2.2 & 1.2 & 2.2 & 1.1 & 1.1 & $\mathrm{~V}$ & Eur. \\
\hline $\mathrm{H}$ & Potentilla tommassiniana & . & . & . & . & 2.3 & 1.2 & 2.3 & 2.2 & + & + & IV & Pont. \\
\hline $\mathrm{H}$ & Potentilla astracanica & . & 1.2 & 1.1 & 1.2 & . & . & 1.2 & 1.1 & . & . & III & Pont. \\
\hline $\mathrm{CH}$ & Goniolimon collinum & . & +.2 & 1.2 & +.2 & . & . & . & . & 1.1 & + & III & Submed. \\
\hline $\mathrm{H}$ & Linum tauricum & . & 1.2 & +.2 & . & . & . & . & . & + & + & III & Balk. \\
\hline $\mathrm{H}$ & Potentilla arenaria & 4.4 & 1.2 & 1.2 & . & . & . & . & . & . & . & II & Pont. \\
\hline $\mathrm{H}$ & Silene paradoxa & . & . & . & . & 1.1 & + & . & . & 1.1 & . & II & Eur. \\
\hline $\mathrm{CH}$ & Euphorbia barrelieri & . & . & . & +.2 & . & . & . & . & + & + & II & Balk. \\
\hline $\mathrm{H}$ & Vincetoxicum hirundinaria [Cynanchum athoum] & . & . & . & . & . & . & . & 1.1 & + & + & II & Eur. \\
\hline \multirow[t]{2}{*}{$\mathrm{H}$} & Echium rubrum & . & + & . & . & . & + & . & . & . & . & I & Pont. \\
\hline & \multicolumn{13}{|c|}{ Character species of class Festuco - Brometea Br.-BI. et R. Tx. 1943} \\
\hline $\mathrm{H}$ & Minuartia verna & +.2 & +.2 & +.2 & 1.2 & 2.2 & 1.2 & . & . & + & 1.1 & $\mathrm{~V}$ & Circump. \\
\hline $\mathrm{H}$ & Centaurea stoebe & 1.2 & 1.2 & +.2 & . & 1.2 & 1.1 & 1.1 & 1.1 & . & . & IV & Euroas. \\
\hline $\mathrm{G}$ & Ornithogallum umbellatum & 1.1 & + & . & + & 1.2 & 1.1 & . & . & 1.2 & 1.2 & IV & Eur. \\
\hline $\mathrm{H}$ & Anthyllis vulneraria & . & . & 1.1 & . & + & 1.2 & + & + & +.1 & 1.2 & IV & Submed. \\
\hline
\end{tabular}




\begin{tabular}{|c|c|c|c|c|c|c|c|c|c|c|c|c|c|}
\hline & Nr. of relevé & 1 & 2 & 3 & 4 & 5 & 6 & 7 & 8 & 9 & 10 & & \\
\hline $\mathrm{H}$ & Stachys scardica & 1.1 & . & 1.1 & 1.1 & 1.1 & 1.1 & . & . & 1.1 & + & IV & Balk. \\
\hline $\mathrm{H}$ & Paronychia kapela & 1.2 & + & + & . & +.1 & . & . & + & +.1 & 1.2 & IV & Eur. \\
\hline $\mathrm{H}$ & Chrysopogon gryllus & . & . & +.2 & +.2 & 2.3 & 1.1 & 1.1 & 1.2 & . & . & IV & Pont. \\
\hline $\mathrm{H}$ & Sanguisorba minor & 1.1 & . & +.2 & +.2 & 1.2 & 1.1 & . & . & . & 1.1 & IV & Euroas. \\
\hline $\mathrm{H}$ & Stachys recta & 1.2 & + & . & . & . & + & . & 1.2 & + & 2.2 & IV & Pont. \\
\hline $\mathrm{H}$ & Leontodon crispus & . & . & + & + & 1.1 & 1.1 & . & . & 1.1 & + & IV & Submed. \\
\hline $\mathrm{H}$ & Sedum acre & . & . & . & . & + & + & + & + & + & + & IV & Euroas. \\
\hline $\mathrm{H}$ & Lotus corniculatus & + & + & + & . & . & + & + & . & . & 1.1 & IV & Euroas. \\
\hline $\mathrm{H}$ & Koeleria gracilis & . & . & . & . & 1.1 & 1.1 & 2.2 & 1.2 & . & + & III & Circump. \\
\hline $\mathrm{CH}$ & Dorycnium pentaphyllum & . & +.2 & . & +.2 & . & . & . & + & 1.2 & + & III & Balk. \\
\hline $\mathrm{H}$ & Convolvulus cantabrica & . & 1.1 & . & + & . & + & + & 1.1 & . & . & III & Submed. \\
\hline $\mathrm{T}$ & Euphrasia pectinata & + & . & 1.2 & + & 1.2 & . & . & 1.2 & . & . & III & Eur. \\
\hline $\mathrm{H}$ & Trinia glauca & + & 1.1 & . & . & . & . & + & 1.1 & + & . & III & Submed. \\
\hline $\mathrm{H}$ & Inula hirta & +.1 & + & . & . & . & . & + & + & . & 1.1 & III & Euroas. \\
\hline $\mathrm{H}$ & Euphorbia cyparissias & . & . & + & + & 1.1 & . & + & . & + & . & III & Eur. \\
\hline $\mathrm{H}$ & Eryngium campestre & + & + & + & + & . & . & . & . & + & . & III & Pont. \\
\hline G & Galium verum & + & . & . & . & + & + & + & . & . & + & III & Euroas. \\
\hline $\mathrm{CH}$ & Teucrium montanum & 1.2 & . & . & +.2 & 1.1 & . & . & . & . & + & III & Eur. \\
\hline $\mathrm{H}$ & Veronica jacquini & . & . & . & + & . & . & . & +.2 & 1.2 & +.2 & III & Pont. \\
\hline $\mathrm{CH}$ & Artemisia alba & . & 1.2 & . & . & . & . & 1.2 & +.1 & + & . & III & Submed. \\
\hline $\mathrm{H}$ & Potentilla argentea & +.2 & . & . & + & . & . & . & . & 1.1 & + & III & Pont. \\
\hline $\mathrm{H}$ & Centaurea splendens & + & . & . & + & . & 2.1 & . & 2.1 & . & . & III & Submed. \\
\hline $\mathrm{H}$ & Hypericum perforatum & . & . & . & . & . & 1.1 & +.1 & + & + & . & III & Cosmop. \\
\hline $\mathrm{G}$ & Orchis morio & . & . & 1.2 & . & + & . & . & + & +.1 & . & III & Med. \\
\hline $\mathrm{H}$ & Thesium ramosum & + & . & +.2 & . & . & . & . & . & + & + & III & Euroas. \\
\hline $\mathrm{G}$ & Colchicum hungaricum & . & . & . & . & + & + & . & . & + & + & III & Balk. \\
\hline $\mathrm{T}$ & Trifolium arvense & + & . & . & . & + & + & . & . & + & . & III & Eur. \\
\hline $\mathrm{H}$ & Filipendula vulgaris & + & + & . & . & + & + & . & . & . & . & III & Circump. \\
\hline $\mathrm{CH}$ & Teucrium polium & +.2 & . & . & +.2 & . & 1.2 & . & . & . & . & II & Submed. \\
\hline $\mathrm{H}$ & Koeleria splendens & . & . & . & . & 1.2 & 1.2 & . & . & . & 1.1 & II & Submed. \\
\hline $\mathrm{H}$ & Prunella laciniata & . & 1.2 & . & + & . & . & . & +.2 & . & . & II & Med. \\
\hline $\mathrm{H}$ & Hippocrepis comosa & . & 1.2 & +.2 & . & . & . & . & . & . & + & II & Submed. \\
\hline $\mathrm{G}$ & Iris reichenbachii & . & . & . & . & + & . & . & . & 1.1 & 1.2 & II & Balk. \\
\hline $\mathrm{H}$ & Stipa pulcherrima & . & . & . & . & 1.1 & 1.1 & . & . & . & + & II & Eur. \\
\hline $\mathrm{T}$ & Aethoinema saxatilis & . & . & . & . & 1.1 & + & . & . & . & 1.1 & II & Submed. \\
\hline $\mathrm{P}$ & Juniperus oxycedrus & . & +.2 & . & . & . & . & . & . & + & + & II & Med. \\
\hline $\mathrm{H}$ & Anthoxanthum odoratum & +.2 & + & . & . & . & . & . & . & . & + & II & Circump. \\
\hline $\mathrm{H}$ & Hieracium bauchinii & . & . & . & . & . & . & 1.1 & + & + & . & II & Eur. \\
\hline $\mathrm{H}$ & Sideritis montana & . & + & . & . & . & + & 1.1 & . & . & . & II & Euroas. \\
\hline $\mathrm{T}$ & Filago arvensis & . & . & . & . & . & . & . & + & + & + & II & Submed. \\
\hline $\mathrm{H}$ & Calamintha acinos & + & . & . & + & . & . & . & . & + & . & II & Med. \\
\hline $\mathrm{H}$ & Orobanche gracilis & . & & . & . & . & + & + & + & . & . & II & Submed. \\
\hline G & Scilla autumnalis & + & . & . & . & . & . & . & . & + & + & II & Med. \\
\hline \multirow[t]{2}{*}{$\mathrm{H}$} & Sedum ochroleucum & . & + & + & . & . & . & . & . & + & . & II & Submed. \\
\hline & Other species & & & & & & & & & & & & \\
\hline $\mathrm{H}$ & Achillea millefolium & + & . & 1.1 & . & 1.1 & . & + & 1.1 & + & . & III & Euroas. \\
\hline $\mathrm{H}$ & Eryssimum diffusum & . & +.2 & + & + & . & . & . & . & + & . & III & Pont. \\
\hline $\mathrm{H}$ & Verbascum phoeniceum & . & . & + & + & . & . & . & + & + & . & III & Euroas. \\
\hline
\end{tabular}




\begin{tabular}{|c|c|c|c|c|c|c|c|c|c|c|c|c|c|}
\hline & Nr. of relevé & 1 & 2 & 3 & 4 & 5 & 6 & 7 & 8 & 9 & 10 & & \\
\hline $\mathrm{H}$ & Carex caryophyllea & . & + & . & + & . & . & . & . & + & + & III & Euroas. \\
\hline $\mathrm{H}$ & Cichorium intybus & . & . & . & . & + & + & + & + & . & . & III & Euroas. \\
\hline $\mathrm{H}$ & Podospermum laciniata & . & . & . & + & 1.1 & . & . & . & . & 1.1 & II & Euroas. \\
\hline $\mathrm{H}$ & Poa bulbosa & . & +.1 & + & . & . & . & . & . & 1.1 & . & II & Eur. \\
\hline $\mathrm{H}$ & Taraxacum officinale & . & . & . & 1.1 & + & . & . & . & . & + & II & Euroas. \\
\hline $\mathrm{CH}$ & Genista tinctoria & . & . & . & . & . & . & . & + & 1.2 & + & II & Euroas. \\
\hline $\mathrm{G}$ & Allium cupani & . & . & . & + & . & . & . & . & + & + & II & Med. \\
\hline $\mathrm{H}$ & Melica ciliata & . & + & . & + & . & . & . & . & + & . & II & Euroas. \\
\hline $\mathrm{H}$ & Dianthus pinifolius & . & + & . & . & . & . & . & + & + & . & II & Balk. \\
\hline $\mathrm{H}$ & Rumex acetosella & + & + & + & . & . & . & . & . & . & . & II & Cosmop. \\
\hline $\mathrm{H}$ & Silene vulgaris & . & . & + & + & . & . & . & . & + & . & II & Euroas. \\
\hline $\mathrm{H}$ & Plantago lanceolata & + & . & . & + & . & . & . & . & + & . & II & Cosmop. \\
\hline $\mathrm{H}$ & Chondrilla juncea & . & . & . & + & . & . & . & . & + & + & II & Cosmop. \\
\hline $\mathrm{G}$ & Jurinea mollis & . & . & . & + & . & . & . & . & . & + & I & Pont. \\
\hline $\mathrm{G}$ & Iris graminea & + & + & . & . & . & . & . & . & . & . & I & Med. \\
\hline $\mathrm{H}$ & Andropogon ischaemum & . & . & + & + & . & . & . & . & . & . & I & Cosmop. \\
\hline $\mathrm{H}$ & Centaurea napulifera & . & + & + & . & . & . & . & . & . & . & $\mathrm{I}$ & Balk. \\
\hline
\end{tabular}

Legend: Balk. $=$ Balkans, Circump. $=$ Circumpolar, Euroas. $=$ Euroasiatic, Eur. $=$ European, Cosmop. $=$ Cosmopolitan, Med. $=$ Medi terranean, Pont. $=$ Pontic, Submed. $=$ Submediterranean. 